\title{
The “Swede” in the Late Nineteenth- and Early Twentieth-Century Russian CUlture- AND His Daughter
}

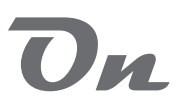
February 28, 1909, Aleksey Venkstern died in Moscow at the age of 52 . No cause of death was indicated-he may have committed suicide.

Venkstern's family was of German-Swedish extraction. Let us take a look at how it came to Russia.

The battle of Lesnaya between Swedish and Russian armies in what is today Belarus took place on September 29, 1708. Although the clash itself was a stalemate, the Swedish withdrawal was so undisciplined and poorly organized that it was tantamount to a defeat, and many Swedes fell behind and were taken prisoner. The loss, in fact, laid the groundwork for Charles XII's historic defeat at Poltava in 1709.

A number of Swedish officers reported missing in action had in reality ended up in captivity. One of them was Jacob Wenckstern, whom the Swedes reported as killed. In reality he soon switched sides, and he was such an able soldier that he came to the attention of Peter the Great himself.

Jacob Wenckstern was the son of Christoffer Wenckstern, who had as a very young man immigrated to Stockholm in 1631 from Germany and made himself a name as a talented and highly skilled bookbinder. Born in 1659, Jacob - the future Yakov Venkstern - was the eldest of nine children, only three of whom survived.

In Russia, Yakov married late in life and had a son named Khristofor, who also became an army officer and in turn fathered 


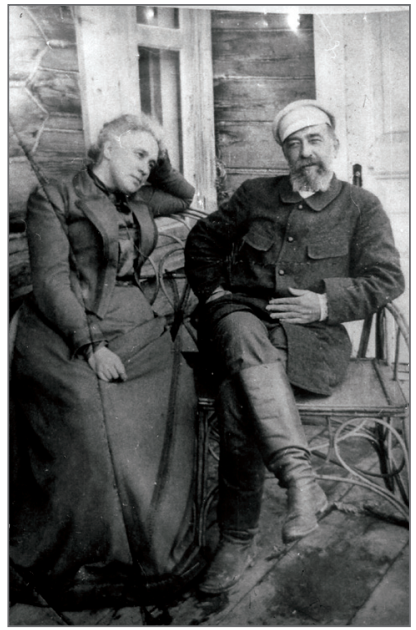

Aleksey Venkstern and his wife Olga a few years before his death.

another Yakov, who made a career in the civil service and attained the rank of Court Counselor. Yakov Jr. married a sister of the philosopher Pyotr Chaadaev and fathered ten children. One of his sons studied together with Mikhail Lermontov, while another, Aleksey, rose to the ranking of gubernial secretary. In the late nineteenth century, his daughter Aleksandra Venkstern became well known as the author of a series of novels with melodramatic plots revolving around love, suicide, and disease, and scored a praise of Lev Tolstoy. Her brother Aleksey was born in 1852, the great-greatgreat-grandson of the Stockholm bookbinder, and he died in 1909. In an obituary of him, Sergey Solovyov noted that, with his light blue eyes and long white beard, Aleksey Venkstern Jr. looked like a Viking. The soul within, however, was more Russian than Swedish. He spent his entire life as an affluent landowner on his family estate, Laptevo, on the border of the Moscow and Tula provinces, but at the time of his death he had been forced to sell his property and was bankrupt.

Those who knew Aleksey Venkstern emphasize his sensual appetite for life and his uniquely broad artistic talent. At the same time, he suffered from manic depression and regularly occurring mood swings. The political resignation that set in after the newly awakened hopes of 1905 in Russian society seems to have interacted with his own unsuccessful financial speculations and his descent into serious depression. In an attempt to escape it Venkstern devoted himself to his hobbies. He led a free and irresponsible life filled with hunting, dog breeding, extravagant parties and wild troika rides. He cultivated all sorts of artistic interests and tried to adopt a kind of artistic lifestyle. Venkstern wrote poems, many of them light pastiches, in the spirit of Pushkin. Published only in periodicals and never 
Double cousins Natalya Venkstern and Sofya Giatsintova, undated.

brought out as a book, they were highly regarded among his acquaintances. In the 1870s and 1880s he had belonged to a legendary amateur Shakespeare society, led by pedagogue and pushkinist Lev Polivanov, which put on plays of considerable aesthetic worth. He himself

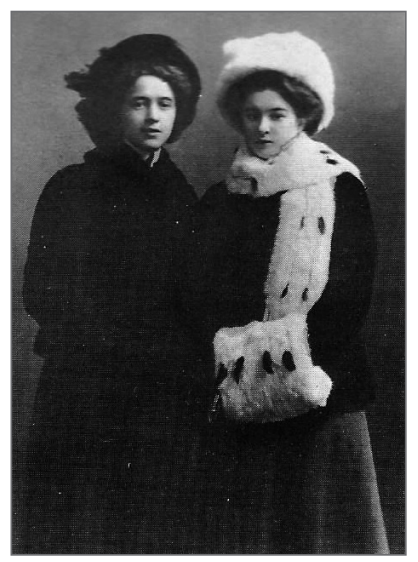
often took the lead roles, giving superb performances as Hamlet, Coriolanus, Henry V, and others. Ivan Turgenev, for one, was occasionally in attendance. Sometimes Aleksey Venkstern, often in collaboration with his brother-in-law, the art historian Vladimir Giatsintov, would himself write plays for the group. His Hamlet is said to be among the best ever seen on the Russian stage. We can surmise that the Danish prince's existential desperation and vacillation on the brink of suicide were themes particularly close to Venkstern's frame of mind.

Being also strongly attracted to Spanish culture, Venkstern had early on traveled to Spain and translated Agustín Moreto y Cabaña's sparklingly witty seventeenth-century comedy Spite for Spite into Russian. A telling choice, the plot centers on a proud, highly accomplished seducer's conquest of an equally proud woman. Venkstern had many affairs that often ended in scandal, but he survived them all and was forgiven by his wife, a Giatsintov whose inherited family traits of patience and a calm sense of duty were the exact opposite of his own.

Aleksey Venkstern's sudden death caused his sixteen-year-old daughter Natalya, who was very devoted to him, to fall seriously ill in the fall of 1909. Her contact with reality was thoroughly and gravely disturbed. She experienced strange somnambulistic states, hallucinations and cramps, and suicidal moods. At times she found it difficult to recognize her own relatives. She was placed in the care of the prominent neurologist Vladimir Rot at the Moscow University Nerve Clinic where she met one of Rot's younger colleagues, 
Aleksandr Vyakhirev, who was interested in the new Freudian therapy that had just been introduced in Russia and decided to try it on her.

Her friend Sergey Solovyov, who after his own father's premature death had come to regard Venkstern as a surrogate father and found a new home in the free bohemian atmosphere of his estate, himself fell ill a short while later. What brought it on was an unhappy love affair with Natalya's "double cousin" - or as she herself called her, her "sister" - Sofya Giatsintova.

How had Natalya's father come to play so central a role in her life that his death gave rise to such serious emotional problems? Father and daughter had been very close to each other, and were said to be much alike both outwardly and inwardly. She had a sister and two brothers, but she was his favorite. Shaped early on by this frivolous artistic milieu, she had inherited his talents and wanted to follow in his footsteps and become an actress.

After completing her first round of therapy with Rot and Vyakhirev, Natalya and her cousin both applied to work under Konstantin Stanislavsky at the Moscow Art Theater. Giatsintova, who was also a Venkstern, but on her mother's side, was admitted and began a promising stage career, but Natalya was not accepted. This failure contributed to the need for more therapy sessions in 1910-1912. An important component of her clinical picture now was her overwrought fixation on Vasily Kachalov, the Art Theater's (and Russia's) leading character actor, who became the new venerated father figure in her life.

In the spring of 1911, a number of professors and lecturers, including Rot and Vyakhirev, left Moscow University to protest the growing political repression. Together with a colleague, in January 1912 Vyakhirev developed the Podsolnechnoye clinic near Moscow into a full-time sanatorium. Natalya Venkstern continued her treatment there at the same time that Sergey Solovyov began psychoanalytical therapy at the nearby Kryukovo sanatorium. This was deep psychology's year in Russia.

Vyakhirev had just published a Russian translation of Freud's Three Essays on the Theory of Sexuality. His intensive therapy appears to have succeeded in strengthening Natalya and freeing her from her 
fixation on Kachalov. Healing may have come at a high and dangerous price, however, for precisely like Sabina Spielrein, the Russian psychoanalytical patient whom Jung treated at the Burghölzli Clinic in Zurich, she fell in love with her savior, and her feelings were reciprocated. In the midst of all this, Vyakhirev died suddenly of appendicitis in the late summer of 1912 while visiting the Venkstern summer home outside Moscow. He had been considered an outstandingly talented therapist. His demise was a hard blow not only for Natalya but for Russian

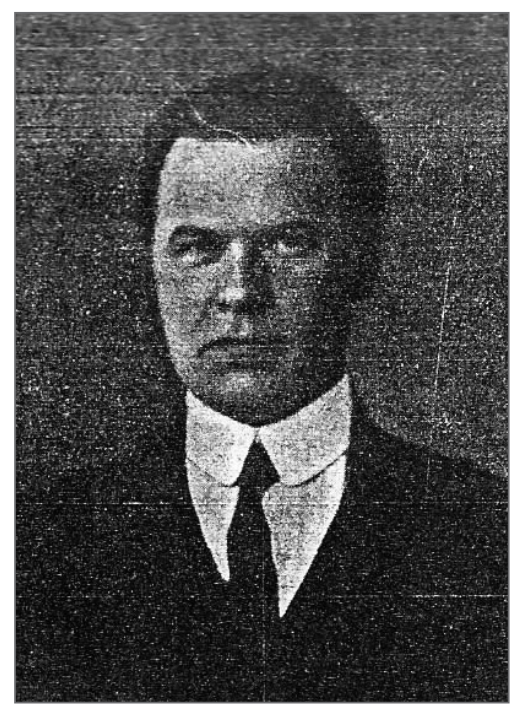

Aleksandr Vyakhirev, undated. psychiatry as well. Things went better for Sergey Solovyov, who was declared cured and got married.

In its second issue of 1914, a few months before the outbreak of WWI, Psikhoterapiya (Psychotherapy), the leading organ for Russian deep psychology, carried an article by Dr. Mikhail Asatiani, Vyakhirev's colleague at Podsolnechnoye. It documented a detailed account of a case of feminine "hysteria" characterized by somnambulism, temporary loss of contact with reality, cramps, and suicidal moods that he claimed he and Vyakhirev had successfully treated. It is difficult to imagine that the woman in question could be anyone but Natalya Venkstern. The patient was said to have undergone successive rounds of therapy between 1909 and 1912 at the Moscow University Nerve Clinic and at Podsolnechnoye. She had a rich imagination and strong literary interests. She was the daughter of a manic depressive (born the same year as Aleksey Venkstern) and grew up on a country estate. She was reported to have two brothers and two sisters, which is correct if we take into account Giatsintova's declaration that from Natalya's early childhood, she was like a sister to her. Asatiani's share of the treatment, which included extensive Jungian association tests, is described in detail. 
The tests indicated an "inversion syndrome," a sexual infirmity related to what Freud describes in Three Essays, the very work Vyakhirev had translated.

Natalya Venkstern recovered enough to be able to work and, following in her father's footsteps here as well, began an entirely new career as a writer. In commemoration of the centennial of the Decembrist uprising, her play 1825 was staged in the fall of 1925 on experimental stage No. 2 at the Moscow Art Theater parallel to and in a close interplay with Bely's new dramatized version of Petersburg. Both plays were directed by Mikhail Chekhov (Anton's nephew), himself influenced

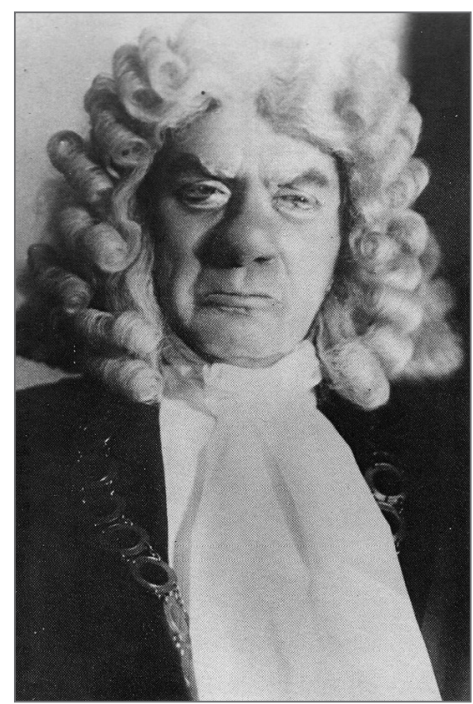

Mikhail Bulgakov as the judge

in The Pickwick $\rho_{\text {apers, }}$

1934. by both psychoanalysis and Anthroposophy, and Sofya in Petersburg was played by none other than Sofya Giatsintova.

While Sofya Giatsintova soon became a celebrated theatre and film actress with a broad repertoire of roles ranging from Ibsen's Nora to Lenin's mother, Natalya made a name for herself in Soviet literature and was very productive despite recurrent psychic problems and an unstable private life. She wrote mostly for the younger generation, but she also became known for her stage adaptations of Dickens's novels. At the Moscow Art Theater she began collaboration - and a long and complex romantic relationship - with a new father figure in her life, Mikhail Bulgakov. It was he who helped her polish the lines of her successful dramatization of The Posthumous Papers of the Pickwick Club, which opened in 1934. Bulgakov himself took part in the play, thereby fulfilling the role of paternal surrogate in a dual sense, as both author and actor. The Pickwick Club was followed 15 years later by Dombey and Son. Some of her adaptations are said to have been adopted by British theaters. 
Natalya and her psychoanalytical experience may have been of assistance to Bulgakov when he himself suffered from psychic problems in the politically tense situation of the 1930s. It was not without reason that his alter ego in his emerging novel The Master and Margarita takes refuge in a mental clinic. It is known that Bulgakov, himself a physician, was interested in psychodynamic therapies.

Sofya Giatsintova had a successful career in Soviet theater that culminated in a Stalin Prize. Natalya remained the same restless spirit as ever up until her death in 1957. As Giatsintova sums her up in her memoirs: "I have never met such a combination of charming, multifaceted talent and deep disharmony." 